\title{
ANALISIS TINGKAT PERTUMBUHAN ASET PADA BPRS MUAMALAT HARKAT KECAMATAN SUKARAJA KABUPATEN SELUMA
}

\author{
Katra Pramadeka ${ }^{1}$, Budi Astuti ${ }^{2}$, Venty Amara Lova ${ }^{3}$ \\ ${ }^{1}$ Institut Agama Islam Negeri Bengkulu \\ ${ }^{2,3}$ Universitas Muhammadiyah Bengkulu \\ E-mail: katra.pramadeka@iainbengkulu.ac.id, budiastuti@gmail.com, ventyamaralova@gmail.com
}

Abstract: The assets growth rate is influenced by several factors, namely internal factors and external factors. By considering these factors, Muamalat Syariah Financing Bank (SFB) Harkat Bengkulu has a strategy so that can always increase from year to year. The strategy used is to develop market share in the form of multi-purpose financing. The problem in this study is, are there any factors that influence the asset growth rate in Muamalat Harkat SFB Sukaraja District, Seluma Regency and what factors influence the assets growth rate in Muamalat Harkat SFB Sukaraja District, Seluma Regency. This study uses qualitative data and uses observation, interviews and documentation as data collection instruments. The results of this study indicate that in increasing asset growth, there are internal factors that consist of employee job performance, job spirits, job discipline, SOP, inspection from Financial Services Authority (FSA/OJK) and internal audit. While the external factors consist of the level of public trust that has begun to grow in the form of savings or deposits, financing, and inspection from external audits.

Keywords: Growth Rate, Assets, BPRS

Abstrak: Tingkat pertumbuhan aset dipengaruhi oleh beberapa faktor yaitu faktor internal dan faktor eksternal. Dengan memperhatikan faktor-faktor tersebut maka Bank Pembiayaan Syariah Muamalat (SFB) Harkat Bengkulu memiliki strategi agar selalu dapat meningkat dari tahun ke tahun. Strategi yang digunakan adalah mengembangkan pangsa pasar dalam bentuk pembiayaan multiguna. Permasalahan dalam penelitian ini adalah adakah faktor-faktor yang mempengaruhi laju pertumbuhan aset di SFB Muamalat Harkat Kecamatan Sukaraja Kabupaten Seluma dan faktorfaktor apa saja yang mempengaruhi tingkat pertumbuhan aset di SFB Muamalat Harkat Kecamatan Sukaraja Kabupaten Seluma. Penelitian ini menggunakan data kualitatif dan menggunakan observasi, wawancara dan dokumentasi sebagai instrumen pengumpulan datanya. Hasil penelitian ini menunjukkan bahwa dalam meningkatkan pertumbuhan aset terdapat faktor internal yang terdiri dari kinerja karyawan, semangat kerja, disiplin kerja, SOP, pemeriksaan dari Otoritas Jasa Keuangan (OJK) dan audit internal. Sedangkan faktor eksternal terdiri dari tingkat kepercayaan masyarakat yang mulai tumbuh berupa tabungan atau deposito, pembiayaan, dan pemeriksaan dari audit eksternal.

Kata kunci: Tingkat Pertumbuhan, Aset, BPRS

\section{A. PENDAHUluaN}

Banyak faktor yang bisa menyebabkan penurunan pertumbuhan total aset bank syariah. Total aset suatu bank sangat dipengaruhi oleh kemampuannya dalam menghimpun dana atau likuiditas dari masyarakat (dana pihak ketiga), semakin besar dana yang dihimpun maka akan semakin besar operasional bank sebaliknya semakin sedikit dana yang dihimpun maka akan sulit bagi bank untuk beroperasi. Dana Pihak Ketiga merupakan dana yang berasal dari masyarakat, sumber dana dari masyarakat ini menjadi penting karena merupakan sumber dana yang digunakan untuk kegiatan operasi bank dan menjadi ukuran keberhasilan bank jika mampu membiayai operasinya dari sumber dana ini. 
Faktor lain yang bisa berpengaruh terhadap pertumbuhan total aset adalah pembiayaan, hal ini sesuai penelitian yang dilakukan oleh Lailiatul Masturoh bahwa terdapat hubungan timbal balik yang saling mempengaruhi antara total aset dengan pembiayaan pada Bank Syariah. ${ }^{1}$ Pembiayaan adalah pembelanjaan, yaitu pendanaan yang dikeluarkan untuk mendukung investasi yang telah direncanakan. ${ }^{2}$ Sehingga pada tahun 2002 sampai 2015 market share pada asset bank syariah belum mencapai target $5 \%$ yang sesuai dengan kebijakan Bank Indonesia dalam cetak biru. Otoritas Jasa Keuangan pada tahun 2015 juga mengeluarkan Roadmap Perbankan Syariah 2015-2019 yang menargetkan market share perbankan syariah. ${ }^{3}$ Dengan adanya target tersebut maka diperlukan evaluasi terhadap pengembangan perbankan syariah agar target 10\% market share pada tahun 2019 dapat tercapai.

Faktor yang menjadi sumber pendapatan utama bank syariah sampai saat ini adalah aset produktif dalam bentuk pembiayaan, karena bank syariah penghimpun dana dari para pemilik modal dan penyalur dana kepada masyarakat. Semakin minim dana yang bisa disalurkan dalam bentuk pembiayaan berarti semakin rendah juga pertumbuhan total asset yang dilaporkan setiap periodenya. Kemudian faktor lain yang bisa mempengaruhi total aset bank syariah adalah jumlah Kantor bank syariah. bahwa jumlah kantor bank syariah secara positif berpengaruh terhadap pertumbuhan bank syariah. Semakin banyak jumlah kantor bank syariah maka akan semakin banyak pula aset yang bisa dikumpulkan.

Dari pemaparan tersebut, menjadi penting untuk mengetahui faktor-faktor apa yang memotivasi masyarakat untuk menyimpan dananya di Bprs Muamalat Harkat, dan mengetahui faktor-faktor apa saja yang mempengaruhi tingkat pertumbuhan aset pada Bprs Muamalat Harkat. Maka judul penelitian yang diangkat adalah "Analisis Tingkat Pertumbuhan Aset Pada BPRS Muamalat Harkat Kecamatan Sukaraja Kabupaten Seluma”

\section{B. METODE PENELITIAN}

Penelitian ini merupakan penelitian lapangan (Field Research). Penelitian lapangan yaitu penelitian yang dilakukan di kancah atau medan terjadinya gejala, untuk mengamati individu, kelompok, lembaga, atau masyarakat. ${ }^{4}$ Penelitian ini merupakan penelitian kualitatif dengan pendekatan deskriptif. Penelitian kualitatif merupakan penelitian yang menghasilkan data deskriptif berupa kata-kata tertulis atau lisan dari orang-orang dan perilaku yang dapat diamati. Menurut Sugiyono menyatakan bahwa metode deskriptif adalah suatu metode yang digunakan untuk menggambarkan atau menganalisis suatu hasil penelitian tetapi tidak

${ }^{1}$ Lailatul Masruroh, "Pengaruh Produk, Pelayanan, Promosi, Dan Bagi Hasil Terhadap Keputusan Masyarakat Memilih Bank Syariah:(Survey Pada BTN Syariah Cabang Surakarta)" (Universitas Muhammadiyah Surakarta, 2007), hlm. 45.

${ }^{2}$ Muhammad, Manajemen Bank Syariah (Yogyakarta: UPP AMP YKPN, 2005), hlm. 304.

${ }^{3}$ Otoritas Jasa Keuangan, "Roadmap Perbankan Syariah Indonesia 2015-2019,” Ojk.Co.Id, last modified 2015, https://www.ojk.go.id/id/kanal/syariah/berita-dan-kegiatan/publikasi/Pages/Roadmap-Perbankan-SyariahIndonesia-2015-2019.aspx.

${ }^{4}$ M.Iqbal Hasan, Pokok-Pokok Materi Metodologi Penelitian Dan Aplikasinya (Jakarta: Ghalia Indonesia, 2002), hlm. 11. 
digunakan untuk membuat kesimpulan yang lebih luas. ${ }^{5}$ Informan Penelitian padan penelitian ini adalah pemangku kepentingan dan karyawan dari pihak BPRS Muamalat Harkat Kecamatan Sukaraja Kabupaten Seluma. teknik pengumpulan data melalui 3 metode yaitu observasi, wawancara dan dokumentasi. Serta metode analisis berdasarkan konsep Miles dan Huberman dengan melalui empat tahap yaitu pengumpulan data, reduksi data, penyajian data dan verifikasi.

\section{HASIL DAN PEMBAHASAN}

Dalam upaya peningkatan keahlian dan pengembangan SDM, Bank Muamalat Harkat pada tahun 2013 mengikutsertakan beberapa orang karyawan dalam pelatihan yang diselenggarakan oleh BI Bengkulu dan Forum Komunikasi BPR se Propinsi Bengkulu serta ASBISINDO. Berikut data tingkat pertumbuhan aset BPRS Muamalat Harkat Kecamatan Sukaraja Kabupaten Seluma

Tabel 1. Tingkat pertumbuhan aset BPRS Muamalat Harkat Kecamatan Sukaraja Kabupaten Seluma

\begin{tabular}{|c|c|c|}
\hline Tahun & Jumlah & Tingkat Pertumbuhan \\
\hline 2016 & 22.887 .346 & $0 \%$ \\
\hline 2017 & 27.546 .649 & $20 \%$ \\
\hline 2018 & 40.595 .760 & $47 \%$ \\
\hline 2019 & 48.981 .644 & $21 \%$ \\
\hline
\end{tabular}

Sumber: BPRS Muamalat Harkat Kecamatan Sukaraja Kabupaten Seluma

Dari data di atas dapat diketahui bahwa tingkat pertumbuhan aset pada tahun 2016 sebesar Rp. 22.887 .346 (0\%), tahun 2017 mencapai Rp. 27.546 .649 (20\%), tahun 2018 Rp. 40.595.760 (47\%), tahun 2019 Rp. 48.981 .644 (21\%).

Setiap bank syariah didirikan dengan tujuan tertentu, misalnya mempertahankan eksistensi, mencapai pertumbuhan tertentu, merebut pangsa pasar, memberikan pelayanan dan meningkatkan jumlah nasabah suatu bank syariah. Pada penelitian ini peneliti menekankan bagaimana suatu bank syariah meningkatkan jumlah nasabah, agar dapat mencapai tingkat pertumbuhan aset tersebut. Dalam BPRS Muamalat Harkat Kecamatan Sukaraja Kabupaten Seluma ada banyak faktor yang mempengaruhi tingkat pertumbuhan aset tersebut.

\section{Faktor-faktor Yang Mempengaruhi Tingkat Pertumbuhan Aset Pada BPRS Muamalat Harkat Bengkulu}

Berdasarkan wawancara dengan bagian umum audit internal BPRS Muamalat Harkat Bengkulu, berpendapat bahwa ada dua faktor yang mempengaruhi tingkat pertumbuhan aset pada BPRS Muamalat Harkat Bengkulu yaitu faktor internal dan faktor eksternal. Dalam meningkatkan pertumbuhan aset, BPRS Muamalat Harkat Bengkulu memiliki strategi agar bisa selalu meningkat dari tahun ke tahun. Strategi yang digunakan yaitu mengembangkan pangsa pasar dalam bentuk pembiayaan "SERUNAI" (Sertifikasi

${ }^{5}$ Sugiyono, Metode Penelitian Kualitatif (Bandung: Alfabeta, 2017), hlm. 98. 
Guru Nuansa Islami) adalah pembiayaan yang ditujukan kepada guru-guru yang menerima tunjangan sertifikasi dari pemerintah baik yang PNS (Pegawai Negeri Sipil) atau NON PNS dengan memotong pendapatan tunjangan sertifikasi. Dengan adanya sertifikasi tersebut aset BPRS Muamalat Harkat Bengkulu mulai ada peningkatan dari tahun ke tahun.

\section{Faktor-faktor Yang Mempengaruhi Tingkat Pertumbuhan Aset Pada BPRS Muamalat Harkat Bengkulu}

Dalam BPRS Muamalat Harkat Bengkulu terdapat dua faktor yang mempengaruhi tingkat pertumbuhan aset yaitu :

\section{a. Faktor Internal :}

1) Kinerja Karyawan

Kinerja seseorang merupakan ukuran sejauh mana keberhasilan seseorang dalam melakukan tugas pekerjaannya. Ada tiga faktor utama yang mempengaruhi kinerja secara umum adalah kemampuan individu untuk melakukan tugas tersebut, tingkat usaha yang dicurahkan dan dukungan organisasi yang diterimanya. Kinerja karyawan sering diartikan sebagai pencapaian tugas, dimana karyawan dalam bekerja harus sesuai dengan program kerja organisasi untuk menunjukkan tingkat kinerja organisasi dalam mencapai visi, misi, dan tujuan organisasi. ${ }^{6}$

Dalam BPRS Muamalat harkat Bengkulu kinerja karyawan sangat berpengaruh terhadap peningkatan pertumbuhan aset, dengan tujuan untuk memotivasi karyawan dalam pencapaian sasaran organisasi dan dalam mematuhi standar perilaku yang telah ditetapkan sebelumnya, agar membuahkan hasil dan tindakan yang di inginkan. Pengukuran kinerja karyawan dapat digunakan untuk menekan perilaku yang tidak semestinya dan untuk merangsang serta menegakkan perilaku yang semestinya diinginkan, melalui umpan balik hasil kinerja pada waktunya serta pemberian penghargaan, baik yang bersifat intrinsik maupun ekstrinsik.

2) Kesemangatan Kerja

Semangat kerja adalah sikap individu dan kelompok terhadap lingkungan kerja dan terhadap kerjasama dengan orang lain yang secara maksimal sesuai dengan kepentingan yang paling baik. Unsur semangat kerja meliputi kegairahan kerja, kepuasan kerja dan adanya kerjasama. ${ }^{7}$ Ada tiga aspek dalam kesemangatan kerja yaitu semangat kelompok yang menggambarkan hubungan antar karyawan, kegairahan yang merupakan motivasi dan dorongan bekerja, dan kualitas untuk bertahan yang merupakan aspek dimana seseorang yang mempunyai semangat kerja yang tinggi maka tidak mudah putus asa dalam menghadapi kesukaran-kesukaran di dalam pekerjaannya.

${ }^{6}$ Whidya Mandasari, “Upaya Peningkatan Kinerja Karyawan Operasional Melalui Motivasi Kerja, Disiplin Kerja, Dan Lingkungan Kerja (Studi Pada Lembaga Penyiaran Publik RRI Semarang),” Jurnal Manajemen UDINUS (2010).

${ }^{7}$ Muh. Alwi, Andi Sylvana, and Risnashari, "Pengaruh Semangat Kerja Pegawai Terhadap Keefektifaan Organisasi Unit Program Belajar Jarak Jauh Universitas Terbuka Makassar,” Jurnal Analisis dan Pelayanan Publik 2, no. 1 (2016), hlm. 33. 
3) Disiplin Kerja

Disiplin kerja adalah suatu kemauan dan kemampuan karyawan untuk dapat mengikuti dan menaati semua peraturan dan standar kerja yang telah ditetapkan oleh perusahaan. Disiplin kerja yang baik akan menunjang tercapainya tujuan dan keberhasilan bagi suatu perusahaan. ${ }^{8}$ Adanya disiplin kerja akan menjamin terpeliharanya tata tertib dan kelancaran pelaksanaan kerja perusahaan, sehingga memperoleh hasil yang optimal. Disiplin kerja dapat dibentuk melalui latihan, pendidikan atau kebiasaan dengan keteladanan tertentu. Selain mengkomunikasikan aturan dengan baik, manajer atau pemimpin juga berperan penting sebagai teladan bagi para bawahannya. Tingkat disiplin kerja yang baik pada akhirnya akan meningkatkan prestasi kerja karyawan. ${ }^{9}$ Bentuk disiplin yang baik akan tercermin pada suasana kerja, sebagai berikut: (1) tingginya rasa kepedulian karyawan terhadap pencapaian perusahaan, (2) tingginya semangat dan gairah kerja dan inisiatif pada karyawan dalam melakukan pekerjaan, (3) besarnya rasa tanggung jawab karyawan untuk melaksanakan tugas dengan sebaik-baiknya, (4) berkembangnya rasa memiliki dan rasa solidaritas yang tinggi dikalangan karyawan, (5) meningkatnya efisiensi, efektifitas, dan produktivitas kerja para karyawan.

4) Standar Operasional Perusahaan ( SOP)

Standar Operasional Perusahaan ( SOP ) dapat didefinisikan sebagai dokumen yang menjabarkan aktivitas operasional yang dilakukan sehari-hari, dengan tujuan agar pekerjaan tersebut dilakukan secara benar, tepat, dan konsisten, untuk menghasilkan produk sesuai standar yang telah ditetapkan sebelumnya. ${ }^{10}$ Standar Operasional perusahaan sangat penting dalam BPRS Muamalat Harkat Bengkulu, karena dengan adanya SOP dapat berpengaruh dalam tingkat pertumbuhan asset pada BPRS Muamalat Harkat tersebut. Standar Operasional Perusahaan juga merupakan pedoman atau acuan dalam bekerja sesuai dengan fungsi dan alat penilaian kinerja pegawai serta sesuai dengan tata kerja, prosedur kerja dan sistem kerja yang berlaku di perusahaan. Tujuan utama dari SOP ini adalah agar proses pelaksaanaan pekerjaan dilakukan dengan rapi, tertib, dan sistematis dari awal hingga akhir. Dengan adanya SOP maka diharapkan kualitas pekerjaan menjadi lebih baik. Fungsi Standar Operasional perusahaan yaitu :

a) Membantu untuk memudahkan pekerjaan para pegawai atau tim dan unit kerja.

b) SOP dapat berfungsi sebagai dasar hukum yang kuat bila terjadi penyimpangan.

c) SOP dapat berfungsi untuk memberikan pengetahuan mengenai hambatanhambatan yang akan dan sedang dialami oleh pegawai.

\footnotetext{
${ }^{8}$ Sri Indra Wahyuni and EMa Fitri Lubis, “Analisis Disiplin Kerja Karyawan Pada PT. Kharisma Dayung Utara Pekanbaru,” Jurnal Valuta 06, no. 01 (2020). hlm. 56.

${ }^{9}$ J. Permatasari, "Pengaruh Disiplin Kerja Dan Motivasi Kerja Terhadap Prestasi Kerja Karyawan (Studi Pada Pt Bpr Gunung Ringgit Malang),” Jurnal Administrasi Bisnis S1 Universitas Brawijaya 25, no. 1 (2015). hlm.2.

${ }^{10}$ Gabriele, "Analisis Penerapan Standar Operasional Prosedur (SOP) Di Departemen Marketing Dan HRD PT. Cahaya Indo Persada,” Jurnal AGORA 6, no. 1 (2018), hlm. 1-10.
} 
d) SOP dapat memberikan arahan kepada para pegawai agar saling menjaga kedisiplinan dalam bekerja.

e) Berfungsi sebagai pedoman dalam pelaksanaan kerja atau tugas.

Adapun tujuan standar operasional perusahaan yaitu Membantu menghindari kesalahan, konflik, keraguan, duplikasi, serta pemborosan, dalam pelaksanaan pekerjaan, Untuk memberikan pedoman atau acuan dalam pelaksanaan pekerjaan, Memberikan ukuran atau parameter dalam penilaian mutu kerja atau pelayanan, dan memberikan jaminan penggunaan semua sumber daya secara efektif dan efisien.

5) Pemeriksaan Dari Pihak OJK Dan Audit Internal

Otoritas Jasa Keuangan (OJK) adalah lembaga yang independen yang mempunyai fungsi, tugas, dan wewenang pengaturan, pengawasan, pemeriksaan, dan penyidikan. OJK dibentuk berdasarkan UU Nomor 21 Tahun 2011 yang berfungsi menyelenggarakan sistem pengaturan dan pengawasan yang terintegrasi terhadap keseluruhan kegiatan di dalam sektor jasa keuangan. Otoritas Jasa Keuangan dibentuk dengan tujuan agar keseluruhan kegiatan di dalam sektor jasa keuangan : 1. Terselenggara secara teratur, adil, transparan, dan akuntabel. 2. Mampu mewujudkan sistem keuangan yang tumbuh secara berkelanjutan dan stabil. 3. Mampu melindungi kepentingan konsumen dan masyarakat.

Audit Internal memiliki peranan penting dalam keberjalanan perusahaan. Audit internal adalah Audit internal merupakan kegiatan yang dilakukan untuk menjamin pencapaian tujuan suatu organisasi. Kegiatan ini dirancang untuk memberikan suatu nilai tambah dalam rangka meningkatkan kualitas dari aktivitas operasional organisasi tersebut. ${ }^{11}$ Audit internal digunakan untuk mendukung keberjalanan manajemen perusahaan sebagai fungsi controlling yang menjamin perusahaan berjalan sesuai dengan perencanaan dan mengarah kepada tujuan.

Adapun tugas audit internal yang dilakukan auditor adalah melakukan audit internal perusahaan dengan menjamin sistem/manajemen yang ada di perusahaan supaya berjalan sesuai yang diinginkan. Selain itu dengan adanya audit internal dapat menghindari adanya resiko kesalahan, penyalahgunaan, dan kendala dengan mengembangkan efisiensi dan efektivitas perusahaan. Oleh karena itu perusahaan seharusnya menyusun SOP audit internal serta melakukan pengendalian internal audit di dalam perusahaan dnegan tujuan pengembangan perusahaan.

\section{b. Faktor Eksternal}

1) Tingkat Kepercayaan masyarakat sudah mulai tumbuh dalam bentuk tabungan atau deposito

Meningkatkan kesadaran masyarakat untuk menabung memang bukan hal yang mudah, namun dalam Bprs Muamalat Harkat Bengkulu tabungan atau deposito kepercayaan masyarakat sudah mulai tumbuh. Produk penghimpunan dana

${ }^{11}$ Radhi Abdul Halim Rachmat, Ivan Gumilar Sambas Putra, and Ii Halilah, "Audit Internal Dan Efektivitas Pengendalian Intern Penjualan,” Jurnal Riset Bisnis dan Investasi 3, no. 3 (2018), hlm. 2. 
merupakan simpanan dana masyarakat yang aman dan sesuai syariah. Diperuntukkan bagi perorangan maupun badan hukum. Selain diberikan bagi hasil/bonus yang kompetitif, simpanan ini juga dijamin oleh Lembaga Penjamin Simpanan ( LPS ) sehingga nasabah akan merasa aman, nyaman dan tenang menyimpan uangnya di Bank Muamalat Harkat. Terbukti dengan adanya LPS tingkat kepercayaan masyarakat yang menabung dibank Muamalat Harkat terus mengalami peningkatan.

2) Pembiayaan

Pembiayaan yang digunakan dalam Bprs Muamalat Harkat yaitu pembiayaan Murabahah. Pembiayaan merupakan salah satu tugas pokok bank, yakni memberikan fasilitas penyediaan dana untuk memenuhi kebutuhan pihak-pihak yang kekurangan dana (defisit unit). Selain dari memberi pinjaman kepada pedagang, petani, umkm, selain itu memberi pinjaman kepada pegawai dalam bentuk pemotongan sertifikasi. Dalam sertifikasi mulai ada peningkatan asset pada Bprs Muamalat Harkat.

3) Pemeriksaan Dari Audit Eksternal

Audit eksternal perlu untuk dilakukan adalah agar masyarakat dapat mengakses informasi tentang penanganan sumber daya ekonomi umum karena masyarakat memang memiliki hal untuk itu. Karena tak semua orang, terutama bagi para awam kesulitan memahami transaksi keuangan dalam bentuk laporan yang rumit, sehingga dibutuhkan jasa seorang profesional untuk memeriksa informasi sekaligus melakukan analisis dalam laporan keuangan tersebut. Untuk memperkecil peluang terjadinya kesalahan di masa mendatang sehingga manajemen perlu melakukan verifikasi akurasi laporan keuangan.

Auditing dapat di definisikan sebagai sebuah proses sistematis yang bertujuan untuk mendapatkan dan mengevaluasi bukti dengan obyektif tentang suatu laporan peristiwa ekonomi. Tujuan dari dilaksanakannya auditing ini adalah menentukan tingkat keakuratan antara laporan tersebut dengan point-point kriteria yang telah ditentukan termasuk dalam penyajian hasilnya kepada pihak yang berkepentingan. ${ }^{12}$ Dalam Bprs Muamalat Harkat, perlu adanya pemeriksaan dari audit eksternal untuk mencegah penyelewengan yang terjadi di dalam perbankan, baik dilakukan oleh atasan maupun karyawannya sendiri.

Setiap bank syariah didirikan dengan tujuan tertentu, misalnya mempertahankan eksistensi, mencapai pertumbuhan tertentu, merebut pangsa pasar, memberikan pelayanan dan meningkatkan jumlah nasabah suatu bank syariah. Dalam tugas akhir ini peneliti menekankan bagaimana suatu bank syariah meningkatkan jumlah nasabah, agar dapat mencapai tingkat pertumbuhan aset tersebut. Dalam BPRS Muamalat Harkat Kecamatan Sukaraja Kabupaten Seluma ada banyak faktor yang mempengaruhi tingkat pertumbuhan aset tersebut. Berdasarkan wawancara dengan bagian umum audit internal BPRS Muamalat Harkat Bengkulu,

\footnotetext{
${ }^{12}$ Istimewa Yogyakarta, Fransiska Desi, and Primastuti Dhini, "Pengaruh Time Budget Pressure Terhadap Kualitas Audit Dengan Independensi Sebagai Variabel Intervening (Studi Kasus Pada Bpk Ri Perwakilan Provinsi Daerah Istimewa Yogyakarta),” Accounting Analysis Journal 3, no. 4 (2014), hlm. 446-456.
} 
berpendapat bahwa ada dua faktor yang mempengaruhi tingkat pertumbuhan aset pada BPRS Muamalat Harkat Bengkulu yaitu faktor internal dan faktor eksternal.

Dalam meningkatkan pertumbuhan aset, BPRS Muamalat Harkat Bengkulu memiliki strategi agar bisa selalu meningkat dari tahun ke tahun. Strategi yang digunakan yaitu mengembangkan pangsa pasar dalam bentuk pembiayaan "SERUNAI" (Sertifikasi Guru Nuansa Islami) adalah pembiayaan yang ditujukan kepada guru-guru yang menerima tunjangan sertifikasi dari pemerintah baik yang PNS (Pegawai Negeri Sipil) atau NON PNS dengan memotong pendapatan tunjangan sertifikasi. Dengan adanya sertifikasi tersebut aset BPRS Muamalat Harkat Bengkulu mulai ada peningkatan dari tahun ke tahun.

Dalam BPRS Muamalat Harkat Bengkulu terdapat dua faktor yang mempengaruhi tingkat pertumbuhan aset yaitu : kinerja karyawan merupakan hasil pekerjaan yang mempunyai hubungan kuat dengan tujuan strategis organisasi, kepuasan konsumen, dan memberikan kontribusi pada ekonomi. pengukuran kinerja merupakan sebuah proses penilaian kemajuan pekerjaan terhadap pencapaian tujuan dan sasaran yang telah ditentukan. Termasuk informasi atas efesiensi penggunaan sumber daya dalam menghasilkan barang dan jasa, kualitas, perbandingan hasil kinerja dengan target dan efektivitas tindakan dalam mencapai tujuan.

Dalam BPRS Muamalat harkat Bengkulu kinerja karyawan sangat berpengaruh terhadap peningkatan pertumbuhan aset, dengan tujuan untuk memotivasi karyawan dalam pencapaian sasaran organisasi dan dalam mematuhi standar perilaku yang telah ditetapkan sebelumnya, agar membuahkan hasil dan tindakan yang di inginkan. Pengukuran kinerja karyawan dapat digunakan untuk menekan perilaku yang tidak semestinya dan untuk merangsang serta menegakkan perilaku yang semestinya diinginkan, melalui umpan balik hasil kinerja pada waktunya serta pemberian penghargaan, baik yang bersifat intrinsik maupun ekstrinsik.

Semangat kerja atau moral kerja itu adalah sikap kesediaan perasaan yang memungkinkan seorang karyawan untuk menghasilkan kerja yang lebih banyak dan lebih tanpa menambah keletihan, yang menyebabkan karyawan dengan antusias ikut serta dalam kegiatankegiatan dan usaha-usaha kelompok sekerjanya, dan membuat karyawan tidak mudah kena pengaruh dari luar, terutama dari orang-orang yang mendasarkan sasaran mereka itu atas tanggapan bahwa satu-satunya kepentingan pemimpin perusahaan itu terhadap dirinya untuk memperoleh keuntungan yang sebesar-besarnya darinya dan memberi sedikit mungkin. Ada tiga aspek dalam kesemangatan kerja yaitu Semangat kelompok menggambarkan hubungan antar karyawan.

Dengan adanya semangat kerja maka karyawan akan saling bekerja sama, tolongmenolong, dan tidak saling bersaing untuk menjatuhkan. Semangat kerja menunjukkan adanya kesediaan untuk bekerja sama dengan orang lain agar orang lain dapat mencapai tujuan bersama. Lingkungan kerja yang baik, menciptakan suasana kerja yang baik pula, kebersamaan diantara karyawan dengan membagi pekerjaan secara adil mampu meningkatkan semangat kerja bagi karyawan itu sendiri. Seseorang yang memiliki kegairahan dalam bekerja berarti juga memiliki motivasi dan dorongan bekerja. Motivasi tersebut akan terbentuk bila seseorang memiliki keinginan atau minat dalam mengerjakan pekerjaannya. Yang lebih dipentingkan oleh 
karyawan adalah seharusnya bekerja untuk organisasi bukan lebih mementingkan pada apa yang mereka dapat. Seseorang yang benar-benar ingin bekerja, akan bekerja dengan baik meskipun tanpa pengawasan dari atasannya dan juga mereka akan bekerja bukan karena perasaan takut tetapi lebih pada dorongan dari dalam dirinya untuk kerja yang tinggi akan menganggap bekerja sebagai sesuatu hal yang menyenangkan bukan hal yang menyengsarakan. Aspek ini tidak langsung menyatakan seseorang yang mempunyai semangat kerja yang tinggi maka tidak mudah putus asa dalam menghadapi kesukaran-kesukaran di dalam pekerjaannya. Ini berarti adanya ketekunan dan keyakinan penuh dalam dirinya.

Tunjangan serta fasilitas yang diberikan oleh perusahaan mampu merangsang semangat kerja karyawan untuk bekerja dengan sungguh-sungguh. Keyakinan ini menunjukkan bahwa seseorang yang mempunyai energi dan kepercayaan untuk memandang masa yang akan datang dengan baik, hal inilah yang meningkatkan kualitas untuk bertahan. Ketekunan mencerminkan seseorang memiliki kesungguhan dalam bekerja. Disiplin kerja yaitu suatu sikap dan perilaku seseorang yang menunjukkan ketaatan,kepatuhan,keteraturan,dan ketertiban pada peraturan perusahaan atau organisasi dan norma-norma sosial yang berlaku. Adanya disiplin kerja akan menjamin terpeliharanya tata tertib dan kelancaran pelaksanaan kerja perusahaan, sehingga memperoleh hasil yang optimal. Sikap disiplin kerja juga dapat diartikan sikap kejiwaan sesorang atau kelompok orang yang senantiasa berkehendak mengikuti atau memenuhi segala aturan atau keputusan yang ditetapkan. Tindakan disiplin digunakan organisasi untuk memberikan sanksi terhadap pelanggaran, sedangkan keluhan digunakan pegawai yang hak-haknya dilanggar oleh organisasi.

Dengan kata lain disiplin kerja pada pegawai sangat dibutuhkan, karena apa yang menjadi tujuan organisasi akan sukar dicapai bila tidak ada disiplin kerja. Agar setiap pekerjaan dapat berjalan dengan lancar, maka harus diusahakan disiplin yang baik. Dengan adanya definisi diatas dapat disimpulkan disiplin pada hakekatnya merupakan pembatasan kebebasan kepada karyawan. Disiplin dalam suatu perusahaan dapat ditegakkan apabila sebagian besar peraturan-peraturannya ditaati oleh sebagian besar para karyawan. Dalam prakteknya untuk mengusahakan seluruh peraturan agar ditaati oleh setiap karyawan. Oleh karena itu dalam praktek bila suatu perusahaan dapat mengusahakan sebagian besar peraturan-peraturan agar ditaati oleh sebagian besar karyawannya maka sebenarnya disiplin sudah dapat ditegakkan.

Bentuk disiplin yang baik akan tercermin pada suasana kerja, sebagai berikut: (1) tingginya rasa kepedulian karyawan terhadap pencapaian perusahaan, (2) tingginya semangat dan gairah kerja dan inisiatif pada karyawan dalam melakukan pekerjaan, (3) besarnya rasa tanggung jawab karyawan untuk melaksanakan tugas dengan sebaik-baiknya, (4) berkembangnya rasa memiliki dan rasa solidaritas yang tinggi dikalangan karyawan, (5) meningkatnya efisiensi, efektifitas, dan produktivitas kerja para karyawan. Standar Operasional Perusahaan ( SOP ) adalah suatu dokumen berisi prosedur kerja yang harus dilakukan secara kronologis dan sistematis dalam menyelesaikan suatu pekerjaan tertentu dengan tujuan agar memperoleh hasil kerja paling efektif. Standar Operasional perusahaan sangat penting dalam BPRS Muamalat Harkat Bengkulu, karena dengan adanya SOP dapat berpengaruh dalam tingkat pertumbuhan asset pada BPRS Muamalat Harkat tersebut. Standar Operasional Perusahaan juga merupakan pedoman atau acuan dalam bekerja sesuai dengan fungsi dan alat 
penilaian kinerja pegawai serta sesuai dengan tata kerja, prosedur kerja dan sistem kerja yang berlaku di perusahaan. Tujuan utama dari SOP ini adalah agar proses pelaksaanaan pekerjaan dilakukan dengan rapi, tertib, dan sistematis dari awal hingga akhir. Dengan adanya SOP maka diharapkan kualitas pekerjaan menjadi lebih baik.

\section{KESIMPULAN}

Perusahaan dengan tingkat Aset yang tinggi dapat dianggap mempunyai risiko yang tinggi, karena perusahaan yang mempunyai laju pertumbuhan tinggi harus dapat menyediakan modal yang cukup untuk membiayai pertumbuhannya. Oleh karena itu variabel pertumbuhan aset besarnya kekayaan akhir perusahaan tersebut semakin besar. Pada tingkat pertumbuhan aktiva yang tinggi, bila besarnya kekayaan akhir tinggi berarti kekayaan awalnya rendah.

Dalam meningkatkan pertumbuhan aset, BPRS Muamalat Harkat Bengkulu memiliki strategi agar bisa selalu meningkat dari tahun ke tahun. Strategi yang digunakan yaitu mengembangkan pangsa pasar dalam bentuk pembiayaan "SERUNAI" (Sertifikasi Guru Nuansa Islami) adalah pembiayaan yang ditujukan kepada guru-guru yang menerima tunjangan sertifikasi dari pemerintah baik yang PNS (Pegawai Negeri Sipil) atau NON PNS dengan memotong pendapatan tunjangan sertifikasi. Dengan adanya sertifikasi tersebut aset BPRS Muamalat Harkat Bengkulu mulai ada peningkatan dari tahun ke tahun. Dalam BPRS Muamalat Harkat Bengkulu juga terdapat dua faktor yang mempengaruhi tingkat pertumbuhan aset yaitu faktor internal dan faktor eksternal. Dalam faktor internal terdiri dari kinerja karyawan, kesemangatan kerja, disiplin kerja, SOP, pemeriksaan dari OJK dan Audit Internal. Sedangkan faktor eksternalnya terdiri dari tingkat kepercayaan masyarakat sudah mulai tumbuh dalam bentuk tabungan atau deposito, pembiayaan dan pemeriksaan dari audit eksternal.

\section{E. DAFTAR PUSTAKA}

Alwi, Muh., Andi Sylvana, and Risnashari. "Pengaruh Semangat Kerja Pegawai Terhadap Keefektifaan Organisasi Unit Program Belajar Jarak Jauh Universitas Terbuka Makassar." Jurnal Analisis dan Pelayanan Publik 2, no. 1 (2016).

Gabriele. "Analisis Penerapan Standar Operasional Prosedur (SOP) Di Departemen Marketing Dan HRD PT. Cahaya Indo Persada.” Jurnal AGORA 6, no. 1 (2018).

Halim Rachmat, Radhi Abdul, Ivan Gumilar Sambas Putra, and Ii Halilah. "Audit Internal Dan Efektivitas Pengendalian Intern Penjualan.” Jurnal Riset Bisnis dan Investasi 3, no. 3 (2018).

Hasan, M.Iqbal. Pokok-Pokok Materi Metodologi Penelitian Dan Aplikasinya. Jakarta: Ghalia Indonesia, 2002.

Indra Wahyuni, Sri, and EMa Fitri Lubis. "Analisis Disiplin Kerja Karyawan Pada PT. Kharisma Dayung Utara Pekanbaru.” Jurnal Valuta 06, no. 01 (2020).

Mandasari, Whidya. "Upaya Peningkatan Kinerja Karyawan Operasional Melalui Motivasi Kerja, Disiplin Kerja, Dan Lingkungan Kerja (Studi Pada Lembaga Penyiaran Publik RRI Semarang)." Jurnal Manajemen UDINUS (2010).

Masruroh, Lailatul. "Pengaruh Produk, Pelayanan, Promosi, Dan Bagi Hasil Terhadap Keputusan Masyarakat Memilih Bank Syariah:(Survey Pada BTN Syariah Cabang Surakarta).”Universitas Muhammadiyah Surakarta, 2007. 
Muhammad. Manajemen Bank Syariah. Yogyakarta: UPP AMP YKPN, 2005.

Otoritas Jasa Keuangan. "Roadmap Perbankan Syariah Indonesia 2015-2019." Ojk.Co.Id. Last modified 2015. https://www.ojk.go.id/id/kanal/syariah/berita-dankegiatan/publikasi/Pages/Roadmap-Perbankan-Syariah-Indonesia-2015-2019.aspx.

Permatasari, J. "Pengaruh Disiplin Kerja Dan Motivasi Kerja Terhadap Prestasi Kerja Karyawan (Studi Pada Pt Bpr Gunung Ringgit Malang)." Jurnal Administrasi Bisnis S1 Universitas Brawijaya 25, no. 1 (2015).

Sugiyono. Metode Penelitian Kualitatif. Bandung: Alfabeta, 2017.

Yogyakarta, Istimewa, Fransiska Desi, and Primastuti Dhini. "Pengaruh Time Budget Pressure Terhadap Kualitas Audit Dengan Independensi Sebagai Variabel Intervening (Studi Kasus Pada Bpk Ri Perwakilan Provinsi Daerah Istimewa Yogyakarta).” Accounting Analysis Journal 3, no. 4 (2014): 446-456. 